\title{
Evolving and contested cultural heritage in China: the rural heritagescape
}

\author{
Marina Svensson \\ Lund University
}

\section{Introduction}

Chinese cultural heritage is complex, contested and evolving. There exist different understandings of the content and value of cultural heritage, and a diverse range of manifestations in terms of images, practices and experiences. Today many different actors are involved in debating, mediating, consuming and managing cultural heritage, in contrast with the situation in the past. Chinese

How to cite this book chapter:

Svensson, M 2016 Evolving and contested cultural heritage in China: the rural heritagescape. In: Matsuda, A and Mengoni, L E (eds.) Reconsidering Cultural Heritage in East Asia, Pp. 31-46. London: Ubiquity Press. DOI: http://dx.doi.org/10.5334/baz.c. License: CC-BY 4.0 
cultural heritage policy takes place in a historically very unique context, namely an authoritarian/Communist market economy with global aspirations. Negotiations and conflicts over the meaning and management of cultural heritage thus occur in the interface of an authoritarian state, market forces and globalisation. Cultural heritage has become important to the Chinese Communist Party (CCP) in its attempt to foster a cultural and national identity in a society where communism is, if not dead, clearly no longer the powerful cohesive force it used to be. Cultural heritage is therefore central for China domestically in its propaganda and educational work, while at the same time it is used to project China's rising international profile and is a pillar of its soft power strategy. Cultural heritage is also becoming an important economic asset for local governments and tourism related industries, something that opens up potential for new contestations. Increasing wealth and leisure time has led to a rapidly growing middle class and a booming cultural, leisure and tourism industry where different types of heritage experiences are on offer. While cultural heritage has then become important for different regions, cities and local communities in their tourism-related branding strategies, certain groups of people are however unhappy at seeing their cultural practices and heritage sites commodified for the benefit of outside visitors. The processes and contestations surrounding cultural heritage are today highly mediated and visualised, in particular thanks to the impact of the Internet, social media and films, which give a new dimension to the production and consumption of cultural heritage, as well as open up new forums for action and debate.

This chapter is divided into two parts. The first part provides an overview of Chinese cultural heritage policy and practice in order to show the impact of ideology and socio-economic changes on the heritage field. The second part illustrates that impact by 
focusing on some dramatic changes in rural heritage, in particular vernacular buildings and traditional belief systems and manifestations, and discusses what this implies for local communities. The aim is to show how different factors, such as a crucial ideological shift, rapid economic development and the emergence of a more plural society with new actors, shape and give rise to new visions and contestations related to cultural heritage in the countryside.

\section{Ideology and power in cultural heritage policy and practice: red heritage, patriotism and the logic of the market}

Cultural heritage policy touches upon issues of cultural and national identity and is therefore contentious and shaped by power relations (Silverman \& Ruggles 2007; Tunbridge \& Ashworth 1995). It is important to address and unpack how cultural heritage policy is related to, and shaped by, political and economic power in society. We need to investigate the nature of the cultural heritage that is being protected, whose heritage this is, why it is being protected, how and by whom. Issues of power, agency and social and political capital thus need to be examined, and in this context we particularly need to identify the official discourse and any counter-hegemonic discourses in society.

Smith's concept of an 'authorised heritage discourse' (AHD) is useful for this purpose (Smith 2006). Smith defines AHD as a set of texts and practices dictating the way in which heritage is defined and employed in a given society. While Smith focuses on AHD in Western societies, it is also possible to identify a Chinese AHD, which, although shaped by China's specific political context and development, is also increasingly influenced by international discourses (Svensson 2011; Wang 2010). The designation of something 
as national heritage tells us what a nation wants to preserve and remember of its past and how it imagines its past. In China's case, the need to make use of cultural heritage for the building of national identity remains strong, but the view of what should be recognised as cultural heritage has undergone significant shifts since 1949.

Generally speaking, we can detect a development over time within the approach to Chinese cultural heritage, from an almost exclusive focus on the revolutionary heritage in the Mao Zedong period, to a focus on China's imperial past and a more culturally based patriotic heritage narrative in the 1980s, to a discovery and celebration of more diverse heritage in the 1990s that also includes vernacular and industrial heritage and finally to the adoption of the concept of intangible cultural heritage since 2000. This development can be traced through studying shifts in ideology and cultural policy that manifest themselves in different heritage and museum policies, sets of heritage listings at the national and local level and in institutional and legislative changes. Regarding physical or 'tangible' cultural heritage, the major actors are the State Administration of Cultural Heritage and the Ministry of Construction, and their equivalents at the provincial, municipal, district and county levels. Regarding intangible cultural heritage, the major actors are the Ministry of Culture and its local offices. But cultural heritage work also involves other institutions and departments, such as government offices responsible for tourism and religious affairs, as well as CCP and its Central Propaganda Department and local offices.

When individuals and groups of people claim or reclaim their identity, or obtain political power, they often challenge or resist the historiography, cultural manifestations and heritage policies of the old political and economic power holders (Harrison 2010). In China, the heritage of so-called 'class enemies', such as capitalists, landlords, lineages and different religious groups, were thus 
in part destroyed, desecrated and forgotten after 1949. Major historic sites and cultural artefacts were reinterpreted and rewritten through an ideological and political lens and presented as feudal, backward and superstitious, and often only preserved because they could serve as monuments of the 'bad' old days of feudalism, colonialism and capitalism. During the Mao era there was thus an almost exclusive focus on and dominance of revolutionary heritage, such as sites associated with revolutionary events and figures, and collections of revolutionary objects exhibited in new revolutionary museums. The attack and destruction of old cultural artefacts and sites reached a feverish height during the Cultural Revolution. Sites and collections considered of national importance, including the Forbidden Palace, were however spared on orders from the highest leadership.

The new economic policy of the 1980s, however, made CCP turn away from the class struggle and revolutionary rhetoric of the past, and instead engage in re-building legal institutions and restoring social relations that were needed in order to develop the nation's economy. This ideological shift also entailed more tolerance of religious beliefs and cultural practices as well as a re-evaluation of China's past. China's rich cultural heritage now became a source of national pride and much work was put into listing, protecting and restoring hitherto neglected sites and buildings. When we look at lists of heritage sites from the late 1980s onwards, we realise how the proportion of revolutionary sites have diminished, giving way to imperial sites, and how the concept of heritage has also expanded to include vernacular buildings in the countryside, for example ancestral halls and whole villages, as well as industrial sites and more recent buildings. Cultural heritage bureaus have been significantly strengthened and given more financial support, and new museums have been built. 
The rapid growth of the number of heritage sites and museums has been impressive. In 1962 the first list of 180 national level protected sites was announced. New rounds of listings have followed at irregular intervals since the early 1980s (1982, 1988, 1996, 2001, 2006 and 2013). Compared with a mere 750 protected sites in 1996, the total number of national sites grew to 4,295 in 2013. While China had only 25 museums in 1949, the number of museums increased exponentially from the 1990s and in particular in recent years. In 2012, 415 new museums opened, making the total number of museums in the country 3,866. In 2006, the first list of intangible heritage included 518 items at the national level, whereas today the number is 1,219. China had its first World Heritage site in 1987 - by 2013 China had 45 World Heritage sites. While the efforts to list heritage sites and build museums have been particularly remarkable since the 1990s, this coincides with the period in which new threats, such as urbanisation, have destroyed much built heritage.

The official Chinese heritage discourse still serves to justify the rule of the Communist Party and its interpretation of history. It is expressed in different policies and laws, and in the selection of protected heritage sites at national, provincial, district and county levels (Svensson 2011). The ideological aspects of cultural heritage are particularly evident in museum work (Denton 2014; Fiskesjö 2010), as well as in the emphasis on patriotic education in schools. While there is still a strong role and place for revolutionary heritage in the Chinese AHD, we also see the emergence of a more culturally based patriotic heritage narrative that celebrates China's imperial history and its artefacts and associated sites. The nationalistic discourse that one can find in so many aspects of contemporary China - for example manifested in the period leading up to and during the Olympic Games in Beijing 
in 2008 - is also found in the cultural heritage field. This includes calls for repatriation and attempts to buy back artefacts plundered from China during the late Qing Dynasty (Fiskesjö 2010; Kraus 2004).

But the official heritage discourse has also changed and developed due to international co-operation and contacts since the 1980s. Although cultural heritage discourse reflects a given society's history and ideological and political system, international organisations - in particular UNESCO and its work on World Heritage Sites (Hevia 2001; Wang 2010) and Intangible Cultural Heritage (Liang 2013; Obringer 2011) - are increasingly shaping the understanding and management of heritage across the World. In China there is a strong push for and interest in having sites listed as World Heritage and an intense competition among different provinces and regions in this respect. In order to have sites and cultural practices listed, China also has to adopt and fulfil the criteria and management laid down by UNESCO, which brings in new perspectives on cultural heritage.

In the past there was a strong focus on physical or tangible cultural heritage, and many sites were celebrated for their age value, architectural specificities, craftsmanship and grandeur, whereas their cultural or religious significance were often downplayed. Gradually, and under strong influence from UNESCO (Liang 2013; Obringer 2011), China has also started to embrace the concept of intangible heritage (feiwuzhi wenhua yichan). China was among the first countries to become a signatory of the UNESCO Convention for the Safeguarding of Intangible Cultural Heritage when it was adopted in 2003. Of 219 items on UNESCO's Representative List of the Intangible Cultural Heritage of Humanity, Chinese entries account for 29. In 2006 China announced its own national level intangible cultural heritage list, and in 2011 a new 
related law was adopted. This has also led to the establishment of new institutions and a new rhetoric surrounding cultural heritage. However, this way of listing and documenting cultural practices and religious ceremonies should be understood not as a growing tolerance of different cultural and religious practices, but as a new way of managing culture and religion (Liang 2013; Oakes 2013).

\section{New actors and voices in cultural heritage work}

In the current political and cultural environment, official cultural heritage discourse and management - manifested through the work and policies of different state bodies such as the State Administration of Cultural Heritage - no longer go unchallenged. In an increasingly plural society with rapidly changing statesociety relations, one finds a multitude of actors that celebrate diverse identities, representations of the past and heritage sites. Competing visions of the past and bottom-up struggles to preserve buildings and rituals now also co-exist or compete with the AHD. Since civil society is heavily controlled in China, there are few NGOs in the field of cultural heritage (an example of such an NGO is the Beijing Cultural Heritage Protection Center). Loose networks have however emerged in recent years on the Internet, celebrating heritage in different cities and regions, or specific types of heritage sites or specific cultural practices. There are also vocal intellectuals and journalists who have used the media and various publication formats to raise concerns over the demolition of old urban neighbourhoods and the disappearance of rural heritage (Svensson 2012a).

In the countryside, one should not forget the role played by lineages and religious associations in protecting and renovating ancestral halls and temples. These groups would usually not be 
recognised as cultural heritage organisations, being fairly loose networks with very little cultural, political and economic power to make their voices heard. The power to define what practices and sites should be elevated to cultural heritage through nominations and listings is tightly controlled by experts, cultural departments and local governments, and there is no open and participatory consultation (Svensson 2011). Nonetheless, lineages and religious associations in rural communities celebrate cultural and religious identities and traditions at local heritage sites or at places that are not always recognised as heritage sites by the state. They also engage in activities that in the past were often dismissed as superstitious and backward but today are increasingly honoured with the term 'intangible cultural heritage'. These historical ironies and the development and implications of the current cultural heritage policy for rural communities will be addressed in the remainder of this chapter.

\section{From feudal buildings and superstitious practices to cultural heritage: the impact of ideological shifts and market forces on the rural heritagescape}

The founding of the People's Republic of China drastically changed the economic, cultural and political life in the countryside. Lineages and religious associations were attacked and dissolved as they were seen as a threat to the CCP's political power. Buildings and land belonging to these groups were confiscated, and ancestor and religious worship forbidden or severely restricted. These attacks aimed both at eliminating traditional power elites, and eradicating and appropriating their symbolic and material manifestations. For example, ancestral halls were turned into socialist spaces, and many of them came to serve as schools, cow pens, storage spaces 
and community centres; ancestral tablets that used to be kept in the halls were removed, traditional carvings were destroyed and placards and writings extolling the virtues of lineages were replaced with revolutionary slogans and portraits of Mao Zedong.

In the 1980s, once the economic reforms had started and the revolutionary rhetoric diminished, many lineages began to reclaim and renovate their ancestral halls, update and compile genealogies and engage in different ancestor ceremonies and ritual festivals. Many lineages also set up small exhibitions about their history in the ancestral halls, including lineage codes and stories of famous ancestors, while also using the halls for ancestor ceremonies and as communal spaces for elderly villagers. They collected money and invested their own labour in this renovation without any support, and often with strong resistance, from local governments. Money was often collected from lineage members living in other places, including abroad, and many small temples were restored with donations from religious believers in the region. For instance, in Zhejiang - where I have conducted fieldwork - ancestor ceremonies and temple fairs in the villages have regained their importance, and as well as serving to create a sense of identity and community, these events strengthen ties with family members who have moved away from the village but who often return for these events.

The official rhetoric has remained highly critical and dismissive of lineages and ancestor ceremonies as examples of 'superstitious, backward and feudal' remnants not fit for a modern civilised peasantry and modern culture, whilst at the same time also worrying about their negative impact on rural governance (Svensson 2012b). Amidst this critique, however, there are also attempts to co-opt and appropriate rural heritage, including lineage history and buildings, as well as temples. 
There are two processes at play here, and they are actually intertwined. On the one hand, as briefly mentioned above, since the mid-1990s vernacular cultural heritage in the countryside, including ancestral halls and whole villages, has been 'discovered' and listed as officially protected heritage. On the other hand, tourism, in which cultural heritage constitutes a valuable asset and attraction, has come to be seen as one way for the Chinese countryside to modernize and be lifted out of poverty (Oakes 2013). In 2003, the State Council announced the first list of national level protected historical villages (lishi wenhua mingcun). By the end of 2010 there were 169 listed villages. Many provinces have also announced provincial level historic villages. In Zhejiang there are a total of 14 national level historic villages and some 78 provincial level protected historic districts and villages. Two villages in China, Xidi and Hongcun, currently enjoy the status of UNESCO World Heritage sites. The Chinese state's view on religion and minority culture wavers between on the one hand suppression and cautious acceptance of some religious practices and sites, and on the other hand the adoption of such practices and sites within a cultural heritage narrative and tourism agenda (Liang 2013; Oakes 2013; Oakes \& Sutton 2010). Rural communities, religious communities and minorities are not passive in this process but are able to take advantage of the cultural heritage discourse and official support for tourism in order to promote their own agenda, identities and beliefs (Oakes \& Sutton 2010). Lineages have for example been able to boost their status and position by appropriating the language of cultural heritage and patriotism. Today, therefore, the 'revival' of lineages and rituals as different forces and processes - including market forces, globalisation, official cultural heritage polices, rural tourism projects and development plans - influence how 


\section{2

rural communities imagine and create a sense of community and place (Svensson 2012a).

However, when ancestral halls and villages are designated as heritage sites, their use and management often changes, and villages and lineages no longer fully control them. Renovations have to be approved by heritage bureaus and to follow certain guidelines. The official cultural heritage discourse celebrates monumentality, age and aesthetic value over cultural and religious practices associated with these sites. Cultural heritage authorities thus tend to see ancestral halls as cultural relics rather than as living monuments to ancestors. This means that when the halls become heritage sites and tourism attractions, the process of museumification starts, often drastically changing the management and use of these spaces. The original practices of local residents are confronted with those of tourists, giving rise to new patterns of use through 'negotiation' of these spaces, or sometimes to resistance and marginalisation of local communities. The form these processes take inevitably differs from village to village.

In the 1990s, many historical buildings, ancestral halls and old villages were designated as tangible cultural heritage, whereas local cultural practices were still neglected and often dismissed by local governments. Today, however, with the acceptance of the concept of intangible heritage, national and local governments have started to list and manage cultural practices and local rituals. Many cultural traditions and practices, including traditional music and opera, minority music and dances, traditional medicine (Orbinger 2011), traditional handicrafts and religious and ritual practices have made it onto heritage lists that exist at the national, provincial and municipal level. Some of these traditions are seen as threatened and therefore given special protection. For example, the Qiang minorities New Year Festival was inscribed on UNESCO's 
Representative List of the Intangible Cultural Heritage of Humanity in need of urgent protection in 2009, since an earthquake in 2008 had destroyed many Qiang villages and put the festival at great risk.

Ancestor ceremonies and temple festivals have in some cases turned into government or tourism sponsored cultural festivals. In one village in Zhejiang, the official promotion of the temple fair downplayed both local lineage and religious associations and marketed the fair as a cultural festival where people could experience rural life and customs in more generic terms. However, it still firmly remains a local affair and villagers return to the village for the ceremony even though tourists and photographers today also crowd the village. In another village in this region, the ancestor ceremonies have been designated as a local level intangible heritage due to the fame of the ancestor.

Both tangible heritage and intangible heritage are seen as important assets that can be marketed for tourism, which is often seen as a way to generate economic growth, lift villages out of poverty and promote modernisation. Tourism has thus been identified as an important tool in the New Socialist Countryside project which aims to modernise the countryside. Rural tourism today includes visits to historic villages, famous temples, scenic areas and so-called nongjia le, small peasant restaurants or inns. The new interest in rural tourism can be compared with similar developments in Europe in the late 19th-century, where, as a reaction to urbanisation and rapid social changes, country life and the rural landscape became an object of a 'romantic gaze' and people felt an urgency to preserve and document villages and rural customs that were rapidly vanishing. Similar processes are at play in China today, where the appreciation of picturesque villages and landscapes also feeds into an aesthetic appreciation manifested in traditional art and poetry. 
Many local communities, including both Han villages and minority villages, are however experiencing rapid social and economic changes that challenge their sense of place and local identity. Many communities increasingly realise that tourism companies control and market their heritage for tourist consumption. In some places, such as Lijiang, a World Heritage Site, the influx of Han-Chinese businessmen and tourists have radically changed the ethnic make-up and the cultural ambience of the historic quarters ( $\mathrm{Su} 2010$, see also Fuquan's chapter in this book).

We have only seen the beginning of a process of museumification or heritagization of the Chinese countryside, although one should remember that much of the countryside is too remote and poor to be of interest to tourists. Many Chinese villages are also facing a serious out-migration that leads to the decrease of younger generations and the sustainability of local culture. Many young people however continue to retain close contacts with their ancestral village through visits during the Chinese New Year, and they invest money in the construction and upkeep of family graves, ancestral halls and temples, as well as contributing to the compilation of new genealogies. There also seems to be a renewed interest in local culture and history among new generations of Chinese people. However, when governments and tour operators elevate villages and their cultural practices to the status of 'heritage', rural life is inevitably changed. As well as bringing new economic possibilities which can enhance but also alter the traditional direction of rural life, the status of 'heritage' also brings new cultural challenges, including the need to cater to visitors who wish to consume an idealised rural life which has little relationship to the reality. The processes of heritagization offer both challenges and opportunities for local communities, as well as 
giving rise to new questions concerning the importance of place and tradition in a post-Communist world.

\section{References}

Chan, S C 2001 Selling the Ancestors' Land: A Hong Kong Lineage Adapts. Modern China, 27: 262-284.

Denton, K 2014 Exhibiting the Past: Historical Memory and the Politics of Museums in Postsocialist China. Honolulu: University of Hawai'i Press.

Fiskesjö, M 2010 The Politics of Cultural Heritage. In: Lee C K and Hsing, Y (eds.) Reclaiming Chinese Society: The New Social Activism. London: Routledge. pp. 225-245.

Harrison, R (ed.) 2010 Understanding the Politics of Heritage. Manchester: Manchester University Press.

Hevia, J L 2001 World Heritage, National Culture, and the Restoration of Chengde. Positions: East Asia Cultures Critique, 9 (1): 219-243.

Kraus, R 2004 When Legitimacy Resides in Beautiful Objects: Repatriating Beijing's Looted Zodiac Animal Heads. In: Gries P H and Rosen, S (eds.) State and Society in 21st-century China: Crisis, Contention, and Legitimation. New York: Curzon. pp. 195-215.

Liang, Y 2013 Turning Gwer Sa La Festival into Intangible Cultural Heritage: State Superscription of Popular Religion in Southwest China. China: An International Journal, 11 (2): $58-75$

Oakes, T and Sutton, D S (eds.) 2010 Faiths on Display: Religion, Tourism and the Chinese State. Lanham, MD: Rowman and Littlefield.

Oakes, T 2013 Heritage as Improvement: Cultural Display and Contested Governance in Rural China. Modern China, 39 (4): 380-407.

Obringer, F 2011 Chinese Medicine and the Enticement of Heritage Status. China Perspectives, 3: 15-22. 
Silverman, H and Ruggles, D F (eds.) 2007 Cultural Heritage and Human Rights. New York: Springer.

Smith, L 2006 Uses of Heritage. London and New York: Routledge. Su, X 2010 Heritage Production and Urban Locational Policy in Lijiang. International Journal of Urban and Regional Research, 35 (6): 1118-1135.

Svensson, M 2011 Cultural Heritage Protection in the People's Republic of China: Preservation Policies, Institutions, Laws, and Enforcement in Zhejiang. In: Burell, $M$ and Svensson, $M$ (eds.) Making Law Work: Chinese Laws in Context. New York: Cornell University Press. pp. 225-266.

Svensson, M 2010 Tourist Itineraries, Spatial Management, and Hidden Temples: The Revival of Religious Sites in a Water Town. In: Oakes, T and Sutton, D S (eds.) Faiths on Display: Religion and Tourism in China. Lanham, MD: Rowman and Littlefield. pp. 211-233.

Svensson, M 2012a Heritage Struggles and Place-makings in Zhejiang Province: Local Media, Cross-regional Media Interactions, and Media Strategies from Below. In: Sun W and Chio, J (eds.) Mapping Media in China: Region, Province and Locality. London: Routledge. pp. 193-211.

Svensson, M 2012b Lineages and the State in Zhejiang: Negotiating and Re-inventing Local History and Heritage. In: Bislev, A and Thøgersen, S (eds.) Organizing Rural China. Lanham, MD: Rowman and Littlefield. pp. 157-172.

Tunbridge, J E and Ashworth, G L 1995 Dissonant Heritage: the Management of the Past as a Resource in Conflict. Chichester: John Wiley.

Wang, D 2010 Internationalizing Heritage: UNESCO and China’s Longmen Grottoes. China Information, 24 (2): 123-147. 